\title{
PEMELIHARAAN POST LARVA (PL4-PL9) UDANG VANNAMEI (Penaeus vannamei) DI HATCHERY PT. BANGGAI SENTRAL SHRIMP PROVINSI SULAWESI TENGAH
}

\author{
Ockstan J. Kalesaran \\ Staf Pengajar pada Program Studi Budidaya Perairan, \\ Fakultas Perikanan dan IImu Kelautan. UNSRAT. Manado 95115.
}

\begin{abstract}
Kalesaran, O.J., 2010. Post Larvae's Maintenance (PL4-PL9) Vannamei shrimp (Penaeus vannamei) in hatchery PT. BANGGAI Sentral Shrimp, Central Sulawesi. Jurnal Perikanan dan Kelautan. Vol VI (1): 58-62.
\end{abstract}

White shrimp culture have been developed in some part of brackish water pond area in Indonesia, either in extensive, semi intensive or intensive technology and it resulted increasing on Indonesian shrimp culture production. At post larval stages, the pleopods become fully developed and functional. The animals grow very fast in terms of size and are able to swim freely although early post larvae are still planktonic.

This research was done to know post larval rearing in Hatchery of PT. Banggai Sentral Shrimp. Preparation of basic facilities such as larval rearing tanks, water supply and aeration system is one of the most important activities in hatchery operation. Good water quality should be strictly maintained especially during this phase of larva rearing.

Keywords: Shrimp culture, post larva.

\section{PENDAHULUAN}

Udang Vannamei (Penaeus vannamei) merupakan spesies introduksi yang dibudidayakan di Indonesia. Udang putih yang dikenal masyarakat dengan vanname ini berasal dari Perairan Amerika Tengah. Udang ini dianggap mampu menggantikan udang windu yang mengalami penurunan produksi pada tahun 1992 karena adanya faktor alami berupa perubahan lingkungan, sebagai akibat dari tingginya produksi dari industri budidaya udang windu yang tidak memperhatikan daya dukung lingkungan terutama daya dukung perairan, dan akhirnya timbul masalah penyakit (Anonimous, 2005). Penurunan produksi udang windu berbalik terbalik dengan tuntutan kebutuhan akan udang di pasar lokal maupun pasar internasional sebagai bahan pangan yang terus meningkat, hal ini karena udang memiliki rasa yang enak dan protein dan protein yang terkandung dalam daging udang, mengandung asam amino esensial yang cukup lengkap dan kandungan lemaknya sedikit (Amri, 2003). Untuk memenuhi permintaan tersebut maka pada tahun 2001 Indonesia sebagai salah satu negara produsen udang membudidayakan udang vannamei (Sunarti, 2001).

Salah satu faktor utama dalam usaha budidaya adalah tersedia benih yang cukup dan kontinu sepanjang tahun. Benur vannamei tidak diperoleh dari alam Indonesia, sehingga kebutuhan benur yang cukup serta berkualitas baik hanya diperoleh dari usaha pembenihan di Hatchery.

\section{METODE PENELITIAN}

Penelitian ini dilakukan dengan metode survey serta ikut aktif dalam usaha pemeliharaan hatchery untuk pengumpulan data primer. Beberapa data sekunder dikumpulkan dari para tenaga/pegawai hatchery. 


\section{HASIL DAN PEMBAHASAN}

\section{Lokasi Hatchery}

PT. Banggai Sentral Shrimp yang berdiri pada tahun 1989 dengan total luas areal 160 ha, terletak di Desa Sisipan, Kecamatan Batui, Kabupaten Luwuk-Banggai, Provinsi Sulawesi Tengah. Harchery berada di daerah pinggiran pantai, dengan batas batas wilayah sebagai berikut:

- Sebelah utara berbatasan dengan staff house PT. Banggai Sentral Shrimp.

- Sebelah Timur Berbatasan dengan laut

- Sebelah Selatan berbatasan dengan laut

- Sebelah Barat berbatasan dengan pertambakan.

Hatchery PT. Banggai Sentral Shrimp terbagi atas beberapa bagian yaitu ruang maturasi, ruang laboratorium, ruang alga, ruang teknikal, ruang larva, dan ruang nursery.

Lokasi dan letak yang strategis serta tersedianya sumber sumber air menjadi faktor penentu keberhasilan usaha budidaya. PT. Banggai Sentral Shrimp dimana kegiatan usahanya terdiri dari pertambakan dan pembenihan dengan tujuan ekspor sangat potensial dalam usaha pembenihan udang.

\section{Pemeliharaan Larva}

Wadah yang digunakan untuk pemeliharaan larva adalah tangki beton berbentuk persegi enam dengan kapasitas $40 \mathrm{~m}^{3}$. Sebelum digunakan, tangki maupun peralatan aerasi dibersihkan sehari sebelum larva ditebar. Proses pencucian tanki sebagai berikut:

- Tanki pemeliharaan larva di cuci dengan air laut.

- Dicuci kembali dengan air laut yang sudah tercampur HCL, perbandingan 9:1.

- Tanki dibilas dengan air laut

- Air laut diisi sampai penuh dan sodium thiosulfat 120 gr ditambahkan.

- Aerasi dihidupkan selama 5 menit, lalu diamkan tanpa aerasi selama 2 jam.

- Tangki dan aerator dibilas kembali dengan air laut.

Sebelum larva ditebar, tangki diisi dengan dengan salinitas 33-34 ppt dan suhu $27-29^{\circ} \mathrm{C}$. Ke dalam tangki ditambahkan EDTA (Ethylene Dimetriltetraacetic Acid) sebanyak $240 \mathrm{ppm}$ yang berfungsi untuk menetralisir unsur unsur logam berat dalam air yang digunakan sebagai media pemeliharaan.

Larva yang baru menetas atau pada stadia naupli sampai stadia PL4 dipelihara dalam tangki larva. Saat stadia PL4, larva dipanen dan dipindahkan ke tangki nursery dengan menggunakan ember 10 liter. Pada saat PL 4, pleopod pleopod larva sudah berkembang dan berfungsi dengan baik sehingga larva dapat berenang bebas.

Penebaran larva dilakukan dengan hati hati. Ember berisi larva diletakkan dipermukaan air, kemudian ember dimiringkan sampai tenggelam. Sedikit demi sedikit air media dalam tangki akan masuk ke dalam ember, demikian sebaliknya larva yang berada dalam ember akan keluar menuju air media dalam tangki. Kepadatan larva dalam tangki nursery kapasitas $30 \mathrm{~m}^{3}$ yakni $1.500 .000-2.000 .000$ ekor.

Selama masa pemeliharaan, larva diberi pakan untuk menunjang kelangsungan hidup dan pertumbuhannya. Pakan diberikan dengan penebaran secara langsung. Larva diberi pakan buatan yang bermerek artemac No. 2, Artemac No. 3, artemac No. 4 dan economac. Pemberian pakan 4 jam sekali atau sebanyak $6 \mathrm{kali} /$ hari. Selain pakan buatan larva juga diberi pakan alami berupa naupli artemia yang diberikan sebanyak $3 \mathrm{kali} /$ hari yakni pukul 12.00, 17.00, 24.00.

Sebelum diberikan pakan buatan ditimbang dulu lalu dilarutkan dalam air laut. Selanjutnya disaring dengan saringan yang berukuran 200 dan 300 mikon. 
Tabel 1. Pemberian pakan buatan di tanki nursery

\begin{tabular}{|c|c|c|c|c|c|}
\hline \multirow[b]{2}{*}{ Stadia } & \multirow{2}{*}{$\begin{array}{c}\text { Banyaknya } \\
\text { Pemberian } \\
\text { pakan }\end{array}$} & \multicolumn{4}{|c|}{ Jenis pakan buatan } \\
\hline & & $\begin{array}{c}\text { Economac } \\
\text { No.2 }\end{array}$ & $\begin{array}{c}\text { Artemac } \\
\text { No. } 2\end{array}$ & $\begin{array}{c}\text { Artemac } \\
\text { No.3 }\end{array}$ & $\begin{array}{c}\text { Artemac } \\
\text { No.4 }\end{array}$ \\
\hline PL 4 & 6 kali & $32 \mathrm{gr}$ & $32 \mathrm{gr}$ & $32 \mathrm{gr}$ & - \\
\hline $\mathrm{PL}$ & & & $20 \mathrm{gr}$ & 50 & - \\
\hline PL6 & 6 kali & $50 \mathrm{gr}$ & $20 \mathrm{gr}$ & $50 \mathrm{gr}$ & - \\
\hline PL7 & 6 kali & $40 \mathrm{gr}$ & - & $40 \mathrm{gr}$ & $50 \mathrm{gr}$ \\
\hline PL8 & 6 kali & $40 \mathrm{gr}$ & - & $40 \mathrm{gr}$ & $60 \mathrm{gr}$ \\
\hline PL9 & 1 kali & $10 \mathrm{gr}$ & - & $10 \mathrm{gr}$ & $10 \mathrm{gr}$ \\
\hline
\end{tabular}

Sedangkan untuk pakan alami bagi larva diberikan naupli artemia. Naupli artemia diperoleh dari hasil penetasan cyst artemia. Telur artemia diperlukan kepadatan $10 \mathrm{gr} /$ liter (Dalam $1 \mathrm{gr}$ berisi 280.000 telur). Waktu penetasan 18 -22 jam artemia sudah dapat dipanen. Waktu dan jumlah artemia yang diberikan dapat dilihat pada tabel 2 .

\section{Manajemen Kualitas Air}

Parameter kualitas air yang diukur pada pemeliharaan PL 4-PL 9 yaitu salinitas dan suhu. Pengukuran suhu dilakukan setiap pagi dan sore hari. Salinitas diukur dengan menggunakan refraktometer dan diukur pada pagi hari saat pengisian air pertama dan saat pernggantian air. Dari hasil pengukuran diperoleh suhu selama pemeliharaan berkisar $27-29^{\circ} \mathrm{C}$ dan salinitas berkisar $33-34 \%$. Kualitas air memegang peranan penting dalam pemeliharaan larva, karena merupakan salah satu faktor penunjang kelangsungan hidup dan pertumbuhan larva udang.

Air yang digunakan oleh Hatchery PT. Banggai Sentral Shrimp berasal dari laut dan sumur air tawar. Semua air yang digunakan baik air laut maupun air tawar telah melalui proses penyaringan dengan menggunakan sand filter, catridge filter dan uv filter. Selain sistem penyaringan, kualitas air dijaga dengan penggantian air, pemberian EDTA (ethylenaediamine) dan dengan aerasi yang cukup. Hal ini diberikan untuk menetralisir unsur logam logam berat yang terkandung di air.

Pada saat larva mencapai stadia PL5 atau pada hari ke-2 dalam tanki nursery dilakukan penambahan volumen air $6 \mathrm{~m}^{3}$ sehingga volumen air menjadi $30 \mathrm{~m}^{3}$. Penggantian air mulai dilakukan saat larva berada pada stadia PL6. Penggantian air dilakukan melalui pipa pembuangan hingga volume tertentu, dan larva akan tertampung pada kolektor sebelum keluar dari pipa pembuangan. Hal ini dilakukan untuk menjaga agar tidak ada larva yang ikut keluar bersama air. Penggantian air di tanki nursery dapat dilihat pada tabel 3 .
Tabel 2. Pemberian Naupli artemia

\begin{tabular}{ccc}
\hline Stadia & $\begin{array}{c}\text { Waktu } \\
\text { pemberian } \\
\text { pakan ( jam) }\end{array}$ & $\begin{array}{c}\text { Jumlah } \\
\text { Artemia } \\
\text { (juta) }\end{array}$ \\
\hline PL4 & 12.00 & 25,0 \\
& 17.00 & 25,6 \\
PL5 & 24.00 & 26,6 \\
& 12.00 & 26,6 \\
& 17.00 & 28,3 \\
PL6 & 24.00 & 28,3 \\
& 12.00 & 28,0 \\
& 17.00 & 29,6 \\
PL\& & 24.00 & 28,1 \\
& 12.00 & 27,8 \\
& 17.00 & 30,7 \\
PL8 & 24.00 & 30,6 \\
& 12.00 & 31,0 \\
PL9 & 17.00 & 32,5 \\
& 24.00 & 34,0 \\
& 12.00 & 8,0 \\
\hline
\end{tabular}

Tabel 3. Penggantian air selama masa pemeliharaan larva

\begin{tabular}{cccc}
\hline Stadia & $\begin{array}{c}\text { Vol. Air } \\
\text { (m3) }\end{array}$ & $\begin{array}{c}\text { Ganti air } \\
\text { (m3) }\end{array}$ & $\begin{array}{c}\text { Debit } \\
\text { (L/10dt) }\end{array}$ \\
\hline PL4 & 24 & & \\
PL5 & 30 & Naik 30 & \\
PL6 & 30 & Turun 20 & 8 \\
PL7 & 30 & Turun 16 & 10 \\
PL8 & 30 & Turun 12 & 11 \\
PL9 & 10 & Turun 10 & 12 \\
\hline
\end{tabular}




\section{Panen}

Saat larva telah mencapai PL10, maka pemanenan sudah dapat dilakukan, namun ada beberapa hal yang harus dilakukan yaitu tes virus terhadap larva, pengujian kualitas larva dan mensirkulasi dengan menggunakan formalin. Tes virus dilakukan 2 hari sebelum panen. Tes virus ini ditujukan bagi Taura Syndrome virus (TSV) dan Infectious Hypodermal dan Infectious Hypodermal Hematopoetic Necrosis virus (IHNNV) dengan mengambil beberapa larva udang kemudian dibawa ke laboratorium.

Pengujian kualitas larva dilakukan sehari sebelum panen dengan cara menurunkan salinitas hingga $0 \mathrm{ppt}$, menurunkan suhu air $15^{\circ} \mathrm{C}$, dan perendaman dalam formalin $20 \mathrm{ppm}$. Masing masing dilakukan selama 15 menit. Bila larva bertahan hidup lebih dari $50 \%$ maka larva berkualitas baik. Setelah pengujian larva, air media pemeliharaan disirkulasi dengan menggunakan formalin. Hal ini bertujuan mempercepat molting pada larva sehingga kulitnya bersih dari bakteri, jamur, dan parasit yang terdapat pada kulit lama. Tahapan proses sirkulasi sebagai berikut:

- Air dikeluarkan hingga $12 \mathrm{~m}^{3}$.

- Tambahkan formalin sebanyak 50 ppm ke dalam media pemeliharaan dan diamkan selama 30 menit.

- Media disirkulasi selama 1 jam.

- Terakhir volume air dinaikkan pada keadaan normal $30 \mathrm{~m}^{3}$. Larva sudah dapat di panen.

Pengangkutan larva ke tambak harus memperhatikan jarak dan waktu. PT. Banggai Sentral Shrimp memiliki dua tempat pembesaran yaitu tambak di desa Sisipan yang jaraknya dekat $\pm 200 \mathrm{~m}$ dari Hatchery dan di Kecamatan Bunta Desa Nuhon jaraknya jauh yakni $\pm 112 \mathrm{~km}$ dari hatchery. Untuk pengangkutan jarak dekat, pengemasan dilakukan dengan menggunakan drum plastik yang dilengkapi aerator. Sedangkan untuk jarak jauh dilakukan dengan cara sebagai berikut:

- Larva diambil dari tangki dengan menggunakan sendok berlubang yang sudah didisain. Larva dihitung untuk mengetahui jumlah larva dalam 1 sendok. Perhitungan 1 sendok berisi 4800 ekor larva.

- Kantung plastik diisi air sebanyak 3 liter dan ditambahkan 5 batu karbon kecil, yang berfungsi menetralisir logam berat.

- Kemudian larva dimasukan ke dalam kantong plastik dengan kepadatan 4.800 ekor/3 liter.

- Oksigen dimasukan ke dalam kantung dan diikat menggunakan karet.

- Kantung dimasukan ke dalam kotak stereofoam, diantara kantung diberi pecahan es.

\section{KESIMPULAN}

- Pemeliharaan larva udang vannamei pada tanki nursery dimulai pada post larva 4 (PL 4), dan dapat dipanen untuk pembesaran di tambak pada usia post larva 10 ( $\mathrm{PL} 10)$. Kepadatan larva dalam tangki berkapasitas $30 \mathrm{~m}^{3}$ yakni 1.500.000-2.000.000 ekor.

- Kualitas air berperan penting untuk pemeliharaan larva, dengan kisaran suhu $27-29^{\circ} \mathrm{C}$.dan salinitas $33-34 \%$. Semua air yang digunakan harus melalui penyaringan dengan sand filter, catridge filter dan uv vilter. Pemberian EDTA, aerasi dan penggantian air yang terkontrol mempengaruhi tingkat kelangsungan hidup larva.

- Sebelum pemanenan dilakukan tes virus terhadap larva, pengujian kualitas larva dan mensirkulasi dengan menggunakan formalin. 


\section{DAFTAR PUSTAKA}

Amri, K., 2003. Budidaya Udang Windu Secara Intensif. Agromedia. Jakarta.

Anonimous., 2005. Prospek Budidaya Udang Putih (Penaeus vannamei) sebagai Pengganti Udang Windu. http://erlakurni.wordpress.com/research/nov2006

Anonimous, 2009. Strategi Pengembangan kawasan Budidaya Udang di Propinsi Sulawesi Tengah. Dinas Kelautan dan Perikanan Daerah Provinsi Sulawesi Tengah.

Darmono, 1991. Budidaya Udang Penaeus. Kanisius, Yogyakarta, 104 hal.

Rufianti I., 2006. Manajemen Akuakultur Payau. Sampah bermanfaat.UGM. Notepad.

Sunarti, 2001. Serangan fajar Vannamei llegal. Perikanan Dan Peternakan No.9 Th ke III Hal 44-45

Supono W, 2008. Evaluasi Budidaya Udang putih (Litopenaeus vannamei) dengan meningkatkan kepadatan tebar di tambak intensif. Fakultas Pertanian Univ, Lampung.

Tumbilung, 2007. Teknik pemeliharaan Post larva udang vannamei di Hatchery Banggai Sentral Shrimp. Laporan magang. Fak. Perikanan Dan IImu Kelautan. UNSRAT Manado. 